\title{
LH release and luteal function in post-partum acyclic ewes after the pulsatile administration of LH-RH
}

\author{
P. J. Wright, P. E. Geytenbeek*, I. J. Clarke† and J. K. Findlay $\dagger$
}

Department of Veterinary Clinical Sciences, University of Melbourne, Werribee, Victoria 3030,

*Waite Agricultural Research Institute, Adelaide, South Australia 5064, and †Medical Research Centre, Prince Henry's Hospital, Melbourne, Victoria 3003, Australia

\begin{abstract}
Summary. The administration of LH-RH in a pulsatile regimen (100 ng i.v./h for $48 \mathrm{~h}$ ) to acyclic ewes 26-30 days post partum increased plasma $\mathrm{LH}$ concentrations, and both the frequency and amplitude of plasma LH pulses. In 12/14 ewes these increases were followed by plasma LH surges similar to the preovulatory surges observed in 10 control cyclic ewes. Subsequent luteal function in the post-partum ewes was deficient. Plasma progesterone was detected in 7/12 post-partum ewes showing plasma LH surges. The concentrations were lower $(1 \cdot 3 \pm 0 \cdot 2 \mathrm{ng} / \mathrm{ml})$ and detected for shorter periods (3-10 days) than in cyclic ewes $(2 \cdot 4 \pm 0.2 \mathrm{ng} / \mathrm{ml}, 12 / 15$ days $)$. In the post-partum ewes the increases in plasma $\mathrm{LH}$ concentrations before the LH surge were higher but of shorter duration than in the cyclic ewes. The inadequate luteal function in the post-partum ewes could therefore have been due to inappropriate LH stimulation of the ovary before the LH surge.
\end{abstract}

\section{Introduction}

We have suggested that ovarian acyclicity in ewes post partum could result from failure of follicular development due to inadequate secretion of $\mathbf{L H}$, which in turn reflects inadequate pulsatile release of LH-RH (Wright, Geytenbeek, Clarke \& Findlay, 1981a). To investigate this suggestion further, the effect of the pulsatile administration of LH-RH on plasma LH levels, the occurrence of an LH surge and subsequent luteal function were examined in acyclic post-partum ewes. The patterns of hormone release in post-partum ewes were compared with those associated with preovulatory follicular development, ovulation and subsequent luteal function in cyclic ewes.

\section{Materials and Methods}

\section{Animals}

Mature anoestrous Merino ewes (Bungaree strain) lambing in April (autumn) and cyclic multiparous ewes from the same flock were studied at Mortlock Experiment Station near Clare, South Australia, in May (breeding season) 1980. The post-partum ewes had lambed 26-30 days before the start of treatments with LH-RH (Group PPrh) or vehicle (Group PPv) and each suckled 1 lamb throughout the period of study. The cyclic ewes (Group $\mathrm{CV}$ ) had not lambed for at least 9 months. Vasectomized rams fitted with Sire-Sine harnesses and raddles were run with the ewes from the start of lambing until 1 month after treatment with LH-RH or vehicle. The teaser rams were not kept with the ewes during the period of treatment (Day -2 to the middle of Day 4) when the ewes were penned in a shed. Daily observations were made to detect ewes in oestrus. During the 
4 weeks before treatment the cyclic ewes showed regular oestrous cycles; the post-partum ewes showed no oestrous activity.

\section{Treatments and blood sampling}

The patterns of release of $\mathrm{LH}$ were assessed in $10 \mathrm{Group} \mathrm{Cv}$ (dioestrous) ewes 13 days after treatment with cloprostenol (Estrumate, I.C.I., Australia; $125 \mu \mathrm{g}$ i.m.) and in 25 anoestrous ewes (Groups PPrh \& PPv). Blood samples $(8 \mathrm{ml}$ ) were taken via jugular venous cannulae every $20 \mathrm{~min}$ for $6 \mathrm{~h}(-18$ to $-12 \mathrm{~h})$. All ewes were then given cloprostenol $(125 \mu \mathrm{g}$ i.m. at $-12 \mathrm{~h})$. Starting $12 \mathrm{~h}$ later (Day 1, $0 \mathrm{~h}$ ) and continuing over $48 \mathrm{~h}$ each ewe received an hourly injection (i.v., via jugular venous cannula) of LH-RH (Lutal, Hoechst A.G., West Germany; $100 \mathrm{ng}$ in $2 \mathrm{ml}$ vehicle $(0 \cdot 154 \mathrm{M}$ $\mathrm{NaCl}, 0 \cdot 1 \% \mathrm{w} / \mathrm{v}$ gelatin)) or of $2 \mathrm{ml}$ vehicle. All of the cyclic ewes received vehicle (Group $\mathrm{Cv}$ ). The post-partum ewes received vehicle (Group PPv, N = 10) or LH-RH (Group PPrh, N = 15).

During treatment, blood samples $(8 \mathrm{ml})$ for LH determination were taken every $20 \mathrm{~min}$ for 3 periods of $3 \mathrm{~h}$ starting at 0,21 and $45 \mathrm{~h}$ (periods 1,2 and 3 respectively). Injections of LH-RH or of vehicle were given on the hour, and blood samples were taken at 10,30 and 50 min after injection. Between these periods of intensive sampling, blood samples were taken every $3 \mathrm{~h}$ immediately before the hourly administration of vehicle or LH-RH. Samples were also taken every $3 \mathrm{~h}$ between 48 and $72 \mathrm{~h}$.

Blood samples $(8 \mathrm{ml})$ for progesterone determination were taken by jugular venepuncture on Days 7, 9, 11, 14, 16, 18, 21, 23 and 25. Progesterone concentrations were also measured in the first blood sample taken from each ewe (at $-18 \mathrm{~h}$, i.e. before cloprostenol injection) and in the sample taken from each ewe at the start of treatment $(0 \mathrm{~h})$ to confirm their reproductive status.

\section{Hormone assays}

Plasma LH levels were measured by a double-antibody radioimmunoassay (Wright et al., 1980). The standard was NIH-LH-S1 8 (biopotency $1.03 \times$ NIH-LH-S1). Hormone concentrations and assay quality control data were calculated using the methods and computer programme of Burger, Lee \& Rennie (1972). The study included 6 assays with mean ( \pm s.e.m.) sensitivity of $0 \cdot 1 \pm 0 \cdot 04$ $\mathrm{ng} / \mathrm{ml}$. The interassay coefficients of variation (CV) were 12,8 and $16 \%$ for plasma pools of $1 \cdot 4,5 \cdot 9$ and $62.3 \mathrm{ng} / \mathrm{ml}$. The intra-assay $\mathrm{CV}$ was $<20 \%$ over the range $3.6 \pm 0.5-71 \pm 5.8 \mathrm{ng} / \mathrm{ml}$. Samples with $\mathrm{LH}$ values above this range were diluted $1: 10$ in assay buffer and reassayed.

Plasma progesterone levels were determined by radioimmunoassay in 16 assays (Hossain, Lee, Clarke \& O'Shea, 1979). The mean sensitivity of the assays was $0.1 \pm 0.01 \mathrm{ng} / \mathrm{ml}$. The inter-assay CVs were 18,16 and $20 \%$ for plasma pools of $1.9,2.4$ and $4.5 \mathrm{ng} / \mathrm{ml}$. The intra-assay CVs were $<10 \%$ over the range of $0.3 \pm 0 \cdot 1$ to $3 \cdot 1 \pm 0.4 \mathrm{ng} / \mathrm{ml}$.

\section{Analysis of results}

Two post-partum ewes (1 vehicle-treated and 1 LH-RH-treated) had detectable plasma progesterone $(>0.1 \mathrm{ng} / \mathrm{ml})$ before the start of treatment; these ewes were therefore rejected from analyses.

Characters reflecting patterns of $\mathrm{LH}$ release were determined from plasma $\mathrm{LH}$ concentrations. The mean plasma LH concentrations and the frequency and amplitude of LH pulses were assessed as described previously (Wright $e t$ al., 1981a). An LH pulse was identified when the plasma concentration in one or a series of samples was at least $1 \mathrm{ng} / \mathrm{ml}$ and greater than the level in preceding and/or following samples by a factor of at least 4 times the coefficient of variation of the assay. Pulse amplitude was the maximum plasma LH concentration associated with the pulse minus the concentration preceding the pulse. 
A plasma LH surge similar to the naturally occurring preovulatory LH surge was considered to have occurred if plasma LH levels were $>10 \mathrm{ng} / \mathrm{ml}$ for $>6 \mathrm{~h}$. The time of onset of the $\mathrm{LH}$ surge was recorded as being when plasma $\mathrm{LH}$ was $>10 \mathrm{ng} / \mathrm{ml}$, the end was when $\mathrm{LH}$ values had returned to $<10 \mathrm{ng} / \mathrm{ml}$. The duration of the surge was taken as the period during which plasma LH levels exceeded $10 \mathrm{ng} / \mathrm{ml}$.

Student's $t$ test and $\chi^{2}$ tests were used as appropriate. The effects of treatment group (vehicletreated cyclic ewes, LH-RH-treated post-partum ewes) and of period (1,2 and 3) on characters reflecting LH release in ewes that showed LH surges were assessed in $2 \times 3$ analyses of variance. Values for periods of coinciding with or following an LH surge were not included in the analysis. All values were presented as means \pm s.e.m.

\section{Results}

Plasma LH concentrations, LH pulse frequencies and amplitudes were similar in cyclic (dioestrous, Group Cv) and post-partum (acyclic; Groups PPrh \& PPv) ewes before treatment (-18 to $-12 \mathrm{~h}$ ) (Table 1).

After cloprostenol treatment there were significant increases in plasma $\mathrm{LH}$ concentrations in the cyclic ewes (for pooled values for periods 1 and $2 ; t=8.2, P<0.001$ ) reflecting increased LH pulse frequency $(t=4.0, P<0.001)$ and amplitude $(t=2.6, P<0.05)$ (Tables $1 \& 2)$. Such

Table 1. Plasma LH concentrations in cyclic (dioestrous) and in acyclic ewes $26-30$ days post partum at -18 to $-12 \mathrm{~h}$ (see text)

\begin{tabular}{|c|c|c|}
\hline & $\begin{array}{c}\text { Cyclic } \\
\text { (dioestrous) }\end{array}$ & $\begin{array}{l}\text { Post partum } \\
\text { (anoestrous) }\end{array}$ \\
\hline Group & $\mathrm{Cr}$ & PPrh, PPv \\
\hline No. of ewes & 10 & 23 \\
\hline \multicolumn{3}{|l|}{ No. of ewes with detectable } \\
\hline $\mathrm{LH}(>0.06 \mathrm{ng} / \mathrm{ml})$ & 10 & 23 \\
\hline No. of ewes with LH pulses & 3 & 10 \\
\hline \multicolumn{3}{|l|}{ Frequency of LH pulses } \\
\hline (pulses $/ 6 \mathrm{~h}$ ) & $0.3 \pm 0 \cdot 15$ & $0.4 \pm 0.12$ \\
\hline LH pulse amplitude $(\mathrm{ng} / \mathrm{ml})$ & $1.3 \pm 0.73$ & $1.6 \pm 0.27$ \\
\hline LH conc. $(\mathrm{ng} / \mathrm{ml})$ & $0.3 \pm 0.03$ & $0.3 \pm 0.04$ \\
\hline
\end{tabular}

Values are means \pm s.e.m.

Table 2. Plasma LH concentrations in ewes in Groups $\mathrm{Cv}$ and PPrh before surges in plasma LH

\begin{tabular}{|c|c|c|c|c|c|c|}
\hline & \multicolumn{2}{|c|}{ Period 1} & \multicolumn{2}{|c|}{ Period 2} & \multicolumn{2}{|c|}{ Period 3} \\
\hline & Group Cv & Group PPrh & Group Cv & Group PPrh & Group $\mathrm{Cv}$ & Group PPrh \\
\hline No. of ewes & 10 & 12 & 10 & $10 \dagger$ & $5 \dagger$ & $0 \dagger$ \\
\hline Plasma LH (ng/ml) & $4 \cdot 0 \pm 1 \cdot 2$ & $7.8 \pm 1.1$ & $3.5 \pm 0.5$ & $5 \cdot 2 \pm 0.7$ & $4 \cdot 3 \pm 0.6$ & \\
\hline $\begin{array}{l}\text { LH pulse frequency } \\
\text { (pulses } / 3 \mathrm{~h} \text { ) }\end{array}$ & $2 \cdot 2+0.3^{*}$ & $3 \cdot 0$ & $2 \cdot 4 \pm 0 \cdot 2^{* *}$ & * 3.0 & $3 \cdot 2+0.3$ & \\
\hline $\begin{array}{l}\text { LH pulse amplitude } \\
(\mathrm{ng} / \mathrm{ml})\end{array}$ & $4.4 \pm 0.7$ & $7 \cdot 4 \pm 0.8$ & $3.4 \pm 0.9$ & $3 \cdot 8 \pm 0.5$ & $3 \cdot 0 \pm 0.4$ & \\
\hline
\end{tabular}

Values are means \pm s.e.m.

+ Fewer ewes than in the previous period due to the deletion from the analysis of ewes showing an LH surge. Values significantly different from 3 pulses $/ 3 \mathrm{~h}:{ }^{*} P<0.05,{ }^{* *} P<0.01$. 
Table 3. Plasma $\mathrm{LH}$ surges $(>10 \mathrm{ng} / \mathrm{ml}$ for $>6 \mathrm{~h}$ ) in ewes in Groups $\mathrm{Cv}$ and PPrh

\begin{tabular}{|c|c|c|}
\hline & Group $\mathrm{Cv}$ & Group PPrh \\
\hline No. of ewes & 10 & 14 \\
\hline $\begin{array}{l}\text { No. of ewes showing an } \\
\text { LH surge }\end{array}$ & 10 & 12 \\
\hline Onset of surge (h) & $47.6 \pm 2.8$ & $30 \cdot 9 \pm 1.9^{*}$ \\
\hline End of surge (h) & $63.7 \pm 2.8$ & $45.9 \pm 4.7^{*}$ \\
\hline Duration of surge $(\mathrm{h})$ & $16.1 \pm 1.5$ & $15 \cdot 0 \pm 0.8$ \\
\hline Time of peak LH value $(\mathrm{h})$ & $52 \cdot 6 \pm 3 \cdot 0$ & $35 \cdot 2 \pm 2 \cdot 1^{*}$ \\
\hline Peak LH conc. $(\mathrm{ng} / \mathrm{ml})$ & $142 \pm 24$ & $140 \pm 23.8$ \\
\hline
\end{tabular}

Values are means \pm s.e.m. 0.001 .

* Significantly different from value for ewes in Group Cv: $P<$

increases were not seen in Group PPv ewes; no LH pulses were observed during periods 1, 2 and 3 and the plasma $\mathrm{LH}$ concentrations were similar $(P>0.05)$ in each period $(0.4 \pm 0 \cdot 1,0.3 \pm 0.06$, $0.4 \pm 0 \cdot 1 \mathrm{ng} / \mathrm{ml}$ ) and to levels before treatment (Table 1).

In ewes in Group PPrh mean plasma LH concentrations, pulse frequencies and amplitudes were greater $(P<0.01, P<0.05, P<0.05)$ than those observed in Group $\mathrm{Cv}$ ewes. LH pulse amplitude decreased $(P<0.05)$ in Groups $\mathrm{Cv}$ and PPrh and LH pulse frequency increased $(P<$ 0.05 ) in Group $\mathrm{Cv}$ as the time of onset of the LH surge approached (Table 2).

Plasma LH surges were observed in 10/10 ewes in Group Cv, 12/14 ewes in Group PPrh and in $0 / 9$ ewes in Group PPv. The LH surge began earlier $(P<0.001)$ after the onset of treatment in Group PPrh ewes than in Group CV ewes. The duration of the LH surge and peak plasma LH concentrations were similar $(P>0.05)$ in these 2 groups (Table 3). The 2 ewes in Group PPrh that failed to show an LH surge had plasma LH concentrations of $4.7 \pm 0.65$ and $13.8 \pm 0.9 \mathrm{ng} / \mathrm{ml}$ and pulse amplitudes of $5.7 \pm 0.71$ and $8.8 \pm 1.3 \mathrm{ng} / \mathrm{ml}$.

Table 4. Comparison of patterns of $\mathrm{LH}$ release in post-partum ewes in Group PPrh showing or not showing evidence of luteal function (plasma progesterone $>0.5 \mathrm{ng} / \mathrm{ml}$ ) by Day 9 after the pulsatile administration of LH-RH

\begin{tabular}{|c|c|c|}
\hline & \multicolumn{2}{|c|}{$\begin{array}{c}\text { Plasma progesterone by } \\
\text { Day } 9\end{array}$} \\
\hline & $>0.5 \mathrm{ng} / \mathrm{ml}$ & $<0.1 \mathrm{ng} / \mathrm{ml}$ \\
\hline No. of ewes & 7 & 5 \\
\hline $\begin{array}{l}\text { Period I } \\
\text { Plasma LH (ng/ml) } \\
\text { Pulse amplitude (ng/ml) }\end{array}$ & $\begin{array}{l}8 \cdot 8 \pm 1 \cdot 5 \\
8 \cdot 4 \pm 1 \cdot 3\end{array}$ & $\begin{array}{l}6.5 \pm 1.4 \\
6.1 \pm 0.6\end{array}$ \\
\hline $\begin{array}{l}\text { Period } 2 \\
\quad \text { Plasma LH (ng/ml) } \\
\text { Pulse amplitude (ng/ml) }\end{array}$ & $\begin{array}{l}6.0 \pm 0.5^{*} \\
4 \cdot 4 \pm 0.5^{*}\end{array}$ & $\begin{array}{l}3 \cdot 2 \pm 1 \cdot 5 \\
2 \cdot 4 \pm 0.4\end{array}$ \\
\hline $\begin{array}{l}\text { LH surge } \\
\text { Onset }(\mathrm{h}) \\
\text { Duration }(\mathrm{h}) \\
\text { Time of peak (h) } \\
\text { Peak conc. }(\mathrm{ng} / \mathrm{ml})\end{array}$ & $\begin{aligned} & 33.7 \pm 2 \cdot 3 \\
& 13.6 \pm 0.9^{*} \pm 0 \\
& 27 \cdot 3 \pm 2 \cdot 5 \\
& 108 \pm 15\end{aligned}$ & $\begin{array}{c}26 \cdot 9 \pm 2 \cdot 6 \\
17 \cdot 0 \pm 1 \cdot 1 \\
32 \cdot 3 \pm 3 \cdot 3 \\
186 \pm 49\end{array}$ \\
\hline
\end{tabular}


By Day 9 plasma progesterone was detected $(>0.5 \mathrm{ng} / \mathrm{ml})$ in $10 / 10,1 / 9$ and $8 / 14$ in ewes in Groups Cv, PPv and PPrh respectively. Of the same 12 ewes in Group PPrh showing an LH surge, 7 had detectable plasma progesterone concentrations $(>0.5 \mathrm{ng} / \mathrm{ml})$ by Day 9 , while $1 / 2$ postpartum ewes not showing an LH surge had detectable plasma progesterone $(0.5 \mathrm{ng} / \mathrm{ml})$ on Day 9 only.

Plasma progesterone concentrations in Group PPrh ewes were lower $(1 \cdot 3 \pm 0.2 \mathrm{ng} / \mathrm{ml})$ and detected for shorter periods (3-10 days) than in Group $\mathrm{Cv}$ ewes $(2 \cdot 4 \pm 0.2 \mathrm{ng} / \mathrm{ml}, 12-15$ days). Plasma progesterone $(>0.5 \mathrm{ng} / \mathrm{ml})$ was also detected in 3 ewes in Group PPv and in 2 ewes in Group PPrh for the first time on Day 25 . No progesterone $(<0 \cdot 1 \mathrm{ng} / \mathrm{ml})$ was detected in the plasma of the remaining post-partum ewes.

In Group PPrh ewes showing LH surges that were not followed by detectable plasma progesterone by Day 9 , the plasma LH concentrations and pulse amplitudes were lower $(P<0.05)$ in period 2, and the duration of the surge was longer $(P<0.05)$ than in Group PPrh ewes showing plasma LH surges and detectable plasma progesterone $(>0.5 \mathrm{ng} / \mathrm{ml}$ ) by Day 9 (Table 4).

On Day 4 all of the cyclic ewes showed oestrus and cycled regularly thereafter. Oestrus was detected in only 1 post-partum ewe (Group PPv) during the period of observation (Day 30 ).

\section{Discussion}

We have shown that hourly treatment with $100 \mathrm{ng} \mathrm{LH}-\mathrm{RH}$ for $48 \mathrm{~h}$ leads to a preovulatory-type plasma LH surge in $85 \%$ of acyclic post-partum ewes. However this treatment was not successful in inducing normal luteal function. Nevertheless the results are consistent with our previous suggestion (Wright et al., 1981a) that ovarian acyclicity in post-partum ewes is due to failure of follicular development, due to inadequate release of $\mathrm{LH}$, reflecting inadequate release of $\mathrm{LH}-\mathrm{RH}$. The plasma LH levels and pulse frequencies in untreated post-partum ewes were significantly less than those associated with preovulatory follicular development in cyclic ewes. That this was not due to insensitivity of the pituitary of post-partum ewes was demonstrated by the responsiveness to LH-RH over $48 \mathrm{~h}$. Ovarian responsiveness to endogenous gonadotrophin in the post-partum ewes can be inferred from the occurrence of plasma LH surges in these ewes of similar magnitude and duration to those in cyclic ewes. The LH-RH-induced increases in basal LH levels probably caused sufficient oestradiol-17 $\beta$ to be secreted from ovarian follicles to stimulate the surge in LH release.

The failure to induce normal luteal function could have been due to inadequate follicular development reflecting inappropriate treatment with $\mathrm{LH}-\mathrm{RH}$, a direct antagonistic action of LHRH on the ovary (Sharpe, 1980), or the action of some other factor associated with post-partum anoestrus such as elevated plasma prolactin levels (Wright, Jenkin \& Heap, 1981b). An inappropriate LH-RH treatment regimen seems the most likely explanation because the patterns of LH release indicated that both the dose of $\mathrm{LH}-\mathrm{RH}$ and the frequency of administration were greater than required to stimulate an $\mathrm{LH}$ release pattern similar to that associated with preovulatory follicular development in cyclic ewes. Furthermore, the duration of LH stimulation of the ovary was shorter in post-partum ewes than in the cyclic ewes due to the more rapid onset of the LH surge, and this may have resulted in insufficient time for proper follicular development. The effects of the pulsatile administration of LH to seasonally anoestrous ewes (McNeilly, O'Connell \& Baird, 1982) suggest that the responses of acyclic post-partum ewes to a regimen involving a frequency of administration of LH-RH of 1 pulse $/ 3 \mathrm{~h}$ for $24 \mathrm{~h}, 1$ pulse $/ 2 \mathrm{~h}$ for $24 \mathrm{~h}$ then hourly pulses for $24 \mathrm{~h}$ should be studied. These workers reported normal luteal function in treated ewes despite elevated plasma prolactin levels.

The reason for the more rapid onset of the $\mathrm{LH}$ surge in LH-RH treated acyclic ewes compared with cyclic ewes is unclear. It could reflect a more rapid rise in plasma oestrogen concentrations in the acyclic ewes, or the ability of exogenous LH-RH to elicit an LH surge from an oestrogensensitized pituitary. It could also reflect a lack of progesterone influence before an induced increase 
in plasma oestrogen levels. Pretreatment of ovariectomized ewes with progesterone delayed the onset of oestrogen-induced plasma LH surges (Karsch, Legan, Ryan \& Foster, 1980). Furthermore, progesterone pretreatment of seasonally anoestrous ewes treated with multiple injections of LHRH resulted in a longer interval to the plasma LH surge and a higher incidence of normal luteal function than in ewes not so pretreated (McLeod, Haresign \& Lamming, 1982).

It is probable that the lack of oestrous behaviour in the LH-RH-treated post-partum ewes reflected a lack of prior exposure to progesterone (Robinson, 1954). This could be overcome by treating the ewes with progesterone before treatment with LH-RH. It is possible, however, that these ewes did come into oestrus associated with the LH surge but that this was not detected as the ewes were not placed with teaser rams until Day 4.

We thank Mrs A. Bartlett, Mrs C. Cocks, Mrs R. Jenner and Mr B. Doughton for skilled technical assistance; Mrs D. Heffernan and Mrs M. Gebert for typing; NIH and Dr H. Papkoff for LH standards; and Hoechst A.G. West Germany for LH-RH. These studies were supported by a grant from the Australian Meat Resarch Committee.

\section{References}

Burger, H.G., Lee, V.W.K. \& Rennie, G.C. (1972) A generalised computer programme for the treatment of data from competitive protein binding assays including radioimmunoassays. J. Lab. Clin. Med.80, 302-312.

Hossain, M.I., Lee, C.S., Clarke, I.J. \& O'Shea, J. (1979) Ovarian and luteal blood flow, and peripheral plasma progesterone levels, in cyclic guinea-pigs. $J$. Reprod. Fert. 57, 167-174.

Karsch, F.J., Legan, S.L., Ryan, K.D. \& Foster, D.L. (1980) Importance of estradiol and progesterone in regulating $\mathrm{LH}$ secretion and estrous behavior during the sheep estrous cycle. Biol. Reprod. 23, 404413.

McLeod, B.J., Haresign, W. \& Lamming, G.E. (1982) Response of seasonally anoestrous ewes to small-dose multiple injections of $\mathrm{Gn}-\mathrm{RH}$ with and without progesterone pretreatment. J. Reprod. Fert. 65, 223-230.

McNeilly, A.S., O'Connell, M. \& Baird, D.T. (1982) Induction of ovulation and normal luteal function by pulsed injections of luteinizing hormone in anestrous ewes. Endocrinology 110, 1292-1299.
Robinson, T.J. (1954) The necessity for progesterone with estrogen for the induction of recurrent estrus in the ovariectomized ewe. Endocrinology 55, 403-408.

Sharpe, R.M. (1980) Extra-pituitary actions of LHRH and its agonists. Nature, Lond. 286, 12-14.

Wright, P.J., Geytenbeek, P.E., Clarke, I.J. \& Findlay, J.K. (1980) Pituitary responsiveness to LH-RH, the occultence of oestradiol-17 $\beta$-induced LH-positive feedback and the resumption of oestrous cycles in ewes post partum. J. Reprod. Fert. 60, 171-176.

Wright, P.J., Geytenbeek, P.E., Clarke, I.J. \& Findlay, J.K. (1981a) Evidence for a change in oestradiol negative feedback and $\mathrm{LH}$ pulse frequency in postpartum ewes. J. Reprod. Fert. 61, 97-102.

Wright, P.J., Jenkin, G. \& Heap, R.B. (1981b) Prolactin and $\mathrm{LH}$ release in response to LH-RH and TRH in ewes at various reproductive stages. $J$. Reprod. Fert. 62, 447-453.

Received 15 March 1982 